\title{
REGIONAL MANAGEMENT OF BUILDING COMPLEX COMPETITIVENESS BASED ON THE MODELING OF INTEGRATION PROCESS
}

\author{
Irina Viktorovna Milgunova*1 Iulia Fedorovna Anoshina ${ }^{2}$ \\ ${ }^{1}$ Southwest State University, Kursk, Russia \\ ${ }^{2}$ K.G. Razumovsky Moscow University of Technologies and Management \\ (the First Cossack University), Russia
}

The present article discusses approaches to the solution of problems of increasing competitive advantages of a building organization. It substantiates the necessity and the main directions of state regulation of building complex activities on the basis of strengthening the integration aspects of regional policy. There has been conducted the comparative analysis of strategies of construction sector development. There have been identified the main types of strategies of construction industry integrated growth to ensure competitiveness. The paper also analyses the competitiveness of construction sector, carries out a PEST analysis of the macro environment of construction industry in the region and forms the profile of external environment to control the competitiveness of the industry.

Key words: Competitiveness, Construction industry, Competitiveness management, Integrat

\section{INTRODUCTION}

The development of market relations places a priority on survival and stable development of domestic enterprises in a competitive environment. During the transition to market relations the Russian economy has formed a number of problems: pooreffectiveness of state support, excessive pricing, lack of working capital and investment, consenescence of the basic production assets, etc. They have influenced the state of the largest Russia's industry - construction to different extents. Creating the main part of productive assets, construction industry largely influences the growth of labor productivity and other economic indicators that determine the efficiency of public production development.

Under such conditions, increasing competitiveness of one of the leading sectors of regional economic complex has a strategic importance. The development and effective functioning of the industry is able not only to maintain, but evento create new jobs to give additional impetus to the development of other related sectors of the national economy. The market mechanism of constructionsectormanagement made it necessary to definethe integral index to assess the competitiveness and system of indicators of its assessment that would take into account the interests of producers, investors, creditors, suppliers, competitors, customers. It would also reflect the peculiarities and specifics of management system, which is possible on the basis of modeling business processes.

\section{METHODOLOGY}

The significant amount of domestic and foreign authors' works are concerned withtheoretical research of competitiveness management problems. The analysis of these works allows drawing the following conclusions:
Firstly, both foreign and domestic scholars have not fully overcome a within-one-discipline approach to the problem of construction industry competitiveness.

Secondly, there is no unified comprehensive approach to the problem of economic management of construction enterprises competitiveness; there is no adequate economic and mathematical models to measure the level of the industry competitiveness.

Thirdly, most domestic works are devoted to the researches aimed at studying and generalization of foreign experience, and its application in the Russian context without the emphasis on the system features of the Russian economy development.

Developing the theory of competition, Professor Fatkhutdinov R. A.generally defines competitiveness as the property of entitiesbeing characterized by the degree of real or potential satisfaction of specific needs in comparison with similar objects represented in the given market [12].

In economic science the theory of competition actualizes the problem of singling out a meso-level, i.e. the level ofindustries in addition to micro-, macro -, and mega levels. The competitiveness of an industry is a relatively new concept that requires clarification and underpinning. First of all, it is necessary to set the boundaries of an industry itself, based on its definition:

1. A set of enterprises that use similar technologies, similar resources, produce and distribute similar products or services that compete in the same consumer market. It is believed that an industry covers production, distribution and consumption of goods or services. It is an economic sector which is needed to determine competitors. 
2. The total number of enterprises managed by one administrative authority. It is a historically formed administrative industry.

To obtain more detailed characteristics the level of competitive advantages of an industry can be assessed by the ratio of labor productivity and costs in similar industries of other nations' economies. The industry's competitiveness is largely determined by the competitiveness of its constituent firms, and, consequently, by the competitiveness of manufactured goods. On the other hand, the state'scompetitiveness and the environment created by it affect the emergence and supporting competitive advantages of its enterprises and industries.

Addressing critical socio-economicchallenges, construction is among the key, fund-creating industries whichlargely determine the pace of economy development. The building complex combines a significant number of participants performing multiple functions that are interdependently related to the realization of construction, reconstruction, technical re-equipment and major repairs of enterprises and facilities of all branches and spheres of the Russian Federation economy.

Building complex, in our view, is a set of industries and organizationscharacterized by close sustainable economic, organizational, technical and technological ties in obtaining the end result - ensuring the production of basic funds of national economy. It is the end result that organizationally connects construction companies and production, as well as other companies into one. From the point of view of the final product it is necessary to consider complex management in construction.

The competitiveness of construction companies in the world market is based upon three components: the quality of the offered products and services, their cost and time of delivery. Competitive advantages of construction companies are ultimately embodied in construction products being realized in the property market, which will allow it to obtain the corresponding effect.

Currently, competitiveness is assessed mainly by four computational methods:

1. based on the comparison of quality and price of facilities;

2. differential method;

3. complex method;

4. mixed method.

Theabove-mentioned methods do not solve completely the problem of estimating the competitiveness of products and do not take into account the dynamics of competitiveness associated with the life cycle of goods or services; they are not adapted to modern market conditions affecting the competitiveness of facilities, including geographical location of the market, advertising support, etc.

After analyzing different approaches to assessing competitiveness, our study proposes a method based on the theory of effective competition. According to the pro- posed methodology, the most competitive construction sector is the one where the work of all enterprises and their units (construction companies and enterprises producing construction materials) is organized best of all. Many factors-resources influence their effectiveness. Therefore,multi-criteria assessment of these resources use is implied here. The method is basedon the evaluation of four group indicators or criteria for thecomplex competitiveness:

1. The performance of the complex: the indicator of production costs; the rate of returns on assets; profitability of the construction work; labor efficiency.

2. Financial position: equity ratio; solvency ratio; absolute liquidity ratio; turnover ratio of circulating funds of enterprises forming a complex.

3. The effectiveness of marketing and promotion: profitability of housing sales; the utilization capacity rate; advertising efficiency factor and sales promotion rate.

4. The competitiveness of construction organizations, enterprises of building materials industry: quality; price.

\section{MAIN PART OF THE ARTICLE}

The basis of a competitive and stable building complex is the state support. The purpose of state regulation of the complex is providing competitiveness in order to improve living standards of the population of a certain region in the future.

In the world practice the role of the state and its bodies in economic management has always been the subject of extensive discussions with scientists and politicians.

In the current context, government regulation involves the ability to predict many factors of development and changes in the external and internal environment: the development of construction market, changes in the level of cooperation and specialization, the internal capacity of organizations and improving the level of selfinvestment, the introduction of new technologies and means of labor, and many others. This allows us to identify promising directions of development and the various "bottlenecks" in the activity of aregional building complex.

In relation to the construction sector of a region state regulation should be based on: active influence on the process of regional production and social infrastructure formation; the formation and implementation of regional environmental policies; the creation and implementation of an active urban policy in the region; determining favorable conditions for the formation of a regional building complex, its structure, both technological and according to the forms of ownership of the production means.

Of course, a number of these necessary aspects has an economic character.However, with regard to the construction, their development and use are of paramount importance for the region. 
One of the main ways to reduce the risks of construction industry functioning is government regulation, which should expressall-national interests and ensure the unity and integrity of the economy. This is achieved by developingmandatory legislation for all subjects and norms of relationships between them. State regulation of economic processes is carriedby various methods that can be divided into two main groups: methods of direct and indirect impact [06]. The basic methods of state regulation and the possibility of their application for construction industry organizations are shown in Table 1.

In our view, strategy can be viewed as a system of control actions aimed at the achievement of targets taking into account available potential and environmental conditions. Thus, the more stable the conditions of an organization existencethat depend on the effectiveness of the state regulation system, the more sustainable a longterm strategy is.

To ensure the competitiveness a construction sector cannot implement only one basic strategy. However, under current conditions effective strategic development of the sector is associated with the companies being included in its structure. It can be obtained by adding new organizational structures. That is, the construction industry needs to adhere to the strategy of integrated growth.

There are three basic types of integrated growth strategies:

- the strategy of backward vertical integration aims at the growth of a firm through the acquisition or strengthening of control over suppliers. A company can either create subsidiaries, engaged in the supply, or acquire companies being already engaged in logistics. The effectiveness ofbackward vertical integration strategy can be accounted for decreasing dependence on the componentsprice fluctuations, sales queries;

- the strategy of vertical integration going forward is reflected in the growth of a firm through the acquisition or strengthening of control over the structures being between the firm and the end user, namely the distribution systems and sales systems. This type of integration is very beneficial, when intermediary services are much extended, or when a firm cannot find reliable intermediaries;

- the strategy of horizontal integration provides for strengthening positions of a company due to the absorption of individual competitors or the acquisition of influence over them [13].

The main features of classification are the following: the level of decision making; the basic concept of achieving competitive advantages; a life cycle stage; the degree of aggressiveness of an organization in the competitive struggle. The last three criteria reflect the level of business strategies. An example classification is shown in Figure 1.
Implementing the strategy of integrated growth will allow a construction sector to select the most appropriate option for further development to enhance its competitiveness - the creation of a vertically integrated building complex.

Vertical integration, as well as integration in general, is not a simple addition, not a mechanical combination of an industry's enterprises. It is their rearrangement being aimed at such kind of integration whenthey become parts of a single whole to achieve overall production and business goals. It results in forming rather complicated organic systems, the individual elements of which being relatively independent, work well together. As a result, a new qualityis obtained, not just the sum of properties of its constituent elements. In relation to the enterprises of construction industry integrating into a single entity - the vertically-integratedbuilding complex - this new system property will mean a synergy effect. In our view, this will give strategic advantages that arise when two or more enterprises are combinedin the hands of a single person. There will be increased performance, productivity and/or lower production costs. In sum, the effect of joint actions is more important than a simple sum of individual efforts.

A vertically integrated construction company is a special organizational form of combination of a construction organization and industrial enterprises. Its functions include industrialized construction from the parts of their own making (large-panel structures, solid elements, etc.) of structures of civil building purposes (mostly residential houses). In this form of organization a company incorporates a closed technological cycle of construction industry -starting from manufacturing building materials and their transporting to the site and ending in building itself and facility commissioning.A vertically integrated building complex reflects the development of all kinds of specialization: industry specialization - construction of residential houses of a certain type; constituent part specialization - serial manufacturing of parts at certain factories, workshops and spans; technological specialization - performance of separate kinds of works (installation, finishing, etc.) by permanent groups (construction brigades, spreads, authorities). Vertical integration is an integrated form of construction based on the concentration of production by uniting different companies which are combined by one purpose - the final product - into a complex enterprise.

Vertical integration is the most progressive method of mass building, an example of equivalence ofan organizational form to the industrial nature of the modern construction industry. Continuous technological process of manufacture, transportation, assembly and other works creates optimal conditions to ensure the strait-line flow organization of construction. Increasing level of specialization allows achieving high production figures at plants, transport and construction facilities. It will be possible to effectively use equipment, machines and mechanisms, to reduce the time and improve the quality of construction [09]. 
Table 1: Methods of direct and indirect state regulation to minimize risks of construction industry organizations

\begin{tabular}{|c|c|c|c|c|c|}
\hline \multicolumn{6}{|c|}{ Methods of regulation } \\
\hline Direct & $\begin{array}{l}\text { For ordering } \\
\text { party (project } \\
\text { owners) }\end{array}$ & $\begin{array}{l}\text { For building } \\
\text { organization }\end{array}$ & Indirect & $\begin{array}{l}\text { For ordering } \\
\text { party (project } \\
\text { owners) }\end{array}$ & $\begin{array}{l}\text { For building } \\
\text { organization }\end{array}$ \\
\hline $\begin{array}{l}\text { 1. Denationalization, } \\
\text { privatization }\end{array}$ & & + & 1. Taxsystem & & + \\
\hline $\begin{array}{l}\text { 2. Certificate of } \\
\text { products and building } \\
\text { materials }\end{array}$ & & + & $\begin{array}{c}\text { 2. Appraisal } \\
\text { technique of } \\
\text { projects efficiency }\end{array}$ & + & \\
\hline $\begin{array}{l}\text { 3. Government price } \\
\text { control }\end{array}$ & + & + & 3. Depreciation policy & & + \\
\hline $\begin{array}{c}\text { 4. Anti- } \\
\text { monopolylegislation }\end{array}$ & & + & $\begin{array}{l}\text { 4. Finance and } \\
\text { creditpolicy }\end{array}$ & + & \\
\hline 5. Work rating & + & + & $\begin{array}{l}\text { 5. Development of com- } \\
\text { petitive projects market }\end{array}$ & & + \\
\hline 6. Public contract & + & + & & & \\
\hline $\begin{array}{l}\text { 7. Subsidization of } \\
\text { small business }\end{array}$ & & + & 6. Cover on risks & & + \\
\hline $\begin{array}{l}\text { 8. Integrated target } \\
\text { programs }\end{array}$ & + & + & $\begin{array}{l}\text { 7. Institute of guarantee } \\
\text { of contractor agreements }\end{array}$ & + & + \\
\hline $\begin{array}{l}\text { 9. Membership in } \\
\text { self-regulatory orga- } \\
\text { nizations }\end{array}$ & + & + & & & \\
\hline
\end{tabular}

\begin{tabular}{|c|c|c|c|}
\hline $\begin{array}{l}\text { Strategies for the } \\
\text { level of decision- } \\
\text { making: corporate, } \\
\text { business, } \\
\text { functional }\end{array}$ & $\begin{array}{l}\text { Basic strategies of } \\
\text { competitiveness: } \\
\text { leadership in cost } \\
\text { saving, product } \\
\text { differentiation, } \\
\text { focused }\end{array}$ & $\begin{array}{l}\text { Strategies } \\
\text { corresponding to } \\
\text { the stage of life } \\
\text { cycle of an } \\
\text { organization } \\
\text { development: } \\
\text { growth, } \\
\text { stabilization, } \\
\text { survival, reduction }\end{array}$ & $\begin{array}{l}\text { Strategies related to } \\
\text { organizations' aggressiveness } \\
\text { in competitive struggle: } \\
\text { - according to competitive } \\
\text { position: } \\
\text { of a leader, of a firm playing } \\
\text { supporting roles, slack } \\
\text { business; } \\
\text { - in accordance with the } \\
\text { direction of actions: offensive, } \\
\text { defensive }\end{array}$ \\
\hline
\end{tabular}

Figure 1: Varieties of building complex strategies

Thus, modern conditions of development of regional construction system show that with the purpose of increasing the effectiveness management entity is constantly changing. The present structure, of course, requires perfection, and the formation of a vertically integrated building complex correlates adequately with the current state of construction in the regions and has the potential to offer, which would eventually lead to increased competitiveness of the industry.
It is also necessary to pay attention to sustainable interaction of globally competitive firms in related industries. M. Porter has proven that a company's achieved high competitiveness extends to its immediate environment - suppliers, customers, competitors. In its turn, the success of the environment has a positive impact on further growth of a company's competitiveness. The result of it is a cluster - a community of geographically concentrated complementary firms of related industries characterized by common activities. 
The formation of clusters affects competitiveness: it increases the productivity of all members of a cluster; ability to innovate; it stimulates new businesses that support innovation and expand cluster boundaries. For the national economy clusters carry out a role of growth points of the domestic market and the base of international expansion. The high competitiveness of a state keeps on strong positions of separate clusters, whereas without them even the most developed economy can yield very mediocre results [10].

As an example, there was consideredthe Kursk Region as a model entity of the Russian Federation, part of the Central Federal District.

The conducted investigation of the construction sector development of the Kursk Region allowed identifying the main problems in the construction industry:

1. Currently there is inadequate funding for the construction sector from all sources with unstable dynamics of investment in fixed asset.

2. Lack of own circulating assets in the organizations of a building complex, the aging of capital funds.

3. The inaccessibility of purchasing residential space for wide groups of the population due to high construction cost.

4. The rising cost of building materials and energy products; poor development of the construction industry; the absence of producing operations using local raw materials and facilities for the production of modern building materials with the use of new technologies, which also leads to higher construction costs.

5. The real cost of one square meter of living space significantly exceeds the approved Federallimit cost.

6. Insufficient allocation of housing certificates, which constrains the solution of the problem of improving the living conditions of preferential categories of citizens established by Federal legislation.

7. There remains a lack of funding of socially significant facilities.

To determine the competitiveness of the industry there was conducted a PEST-analysis of the macro environmentof the Kursk Region construction industry, the results of which are shown in Table 2.

Having identified by expertise the influence of factors on an enterprise and the importance for the industry (according to the scale from 1 to 3 ), as well as the direction of influence, we have made a profile of the external environment of an organization, (Table 3).

Thus, it is possible to identify factors that pose a threat (changes in tax policy and small business development) and provide new opportunities (increased solvency of the population, growth of living standards, development of scientific and technical progress and the emergence of new technologies, etc.).

The study calculated the competitiveness of the construction industry in six regions of the Central Federal
District: the Belgorod Region (1), the Voronezh Region (2), the Kursk Region (3), the Lipetsk Region (4), the Oryol Region (5), the Tambov Region (6). In further calculations they will be denoted by the figures noted in brackets.

In relation to construction industry all the factors of competitiveness can be classified into three groups: investments; scope of work performed in the type of activity "Building"; commissioning of production capacities (Figure 2).

Each group includes specific criteria of competitiveness:

1. Co - the competitiveness of the industry:

1.2. In - investments:

1.2.1. A1 - the investments directed to the development of production base of construction organizations;

1.2.2. A2 - the volume of investments in fixed capital at the expense of all sources of funding;

1.2.3. A3 - the investment in fixed capital in agriculture.

1.3. Vp - the volume of construction materials production:

1.3.1. B1 - the production of reinforced concrete products;

1.3.2. B2 - the volume of woodworking production;

1.3.3. B3 - average annual production of bricks;

1.3.4. B4 - average monthly nominal accrued wages of employees;

1.3.5. B5 - glass production;

1.3.6. B6 - cement production;

1.3.7. B7 - production level of fine-dispersed chalk.

1.4. $\mathrm{Pm}$ - commissioning of production facilities:

1.4.1. V1 - commissioning of buildings of residential and non-residential purposes;

1.4.2. V2 - the commissioning of residential houses;

1.4.3. V3 - commissioning of apartments per 1,000 of population (units);

1.4.4. V4 - commissioning of gas networks;

1.4.5. V5 - average prices in the primary housing market;

1.4.6. V6 - average prices in the secondary housing market.

In general, the hierarchy of competitiveness factors includes three levels. To calculate the weighting factors of the analyzed indicators there has been used an analytic hierarchy process (AHP) by [11]. There have been filled the matrices of judgmentsby expertiseaccordingto AHP scale for each group of factors of the I-th and II-th levels. 
Table 2: PEST - analysis of construction industry

\begin{tabular}{|c|c|c|c|}
\hline P & Policy & E & Economy \\
\hline 1 & State regulation in the industry & 1 & Inflation growth rate \\
\hline 2 & $\begin{array}{c}\text { National project "Affordable and } \\
\text { comfortable housing" }\end{array}$ & 2 & $\begin{array}{c}\text { Increasing electricity, water tariffs and } \\
\text { other resources }\end{array}$ \\
\hline 3 & Federal Target Program“Housing" & 3 & Price increase of raw materials \\
\hline 4 & Changes in tax policy & 4 & Population mobility growth \\
\hline 5 & $\begin{array}{c}\text { Changes in the Civil Code of the } \\
\text { Russian Federation }\end{array}$ & 5 & $\begin{array}{c}\text { Improving the solvency of the population } \\
\text { (including through loans) }\end{array}$ \\
\hline S & Society & T & Technology \\
\hline 1 & $\begin{array}{c}\text { Growth in the living standard of the } \\
\text { population }\end{array}$ & 1 & $\begin{array}{c}\text { Development of scientific and technical } \\
\text { progress }\end{array}$ \\
\hline 2 & $\begin{array}{c}\text { Increased number of families not } \\
\text { provided with housing }\end{array}$ & 2 & $\begin{array}{c}\text { The advent of new technologies, } \\
\text { equipment, materials }\end{array}$ \\
\hline 3 & The development of small business & 3 & $\begin{array}{c}\text { State support for innovation, } \\
\text { intellectual property }\end{array}$ \\
\hline 4 & $\begin{array}{c}\text { The development of information } \\
\text { technologies }\end{array}$ & 4 & \\
\hline
\end{tabular}

Table 3: Profile of the external environment

\begin{tabular}{|c|c|c|c|c|}
\hline Factors of environment & $\begin{array}{l}\text { Importance for } \\
\text { the industry, A }\end{array}$ & $\begin{array}{l}\text { Influence on an } \\
\text { organization, B }\end{array}$ & $\begin{array}{l}\text { Direction of } \\
\text { influence, C }\end{array}$ & $\begin{array}{c}\text { Degree of } \\
\text { importance, } \\
D=A^{*} B^{*} C\end{array}$ \\
\hline State regulation in the industry & 3 & 2 & -1 & -6 \\
\hline $\begin{array}{l}\text { National project "Affordable and } \\
\text { comfortable housing" }\end{array}$ & 2 & 3 & +1 & +6 \\
\hline Federal Target Program"Housing" & 2 & 2 & +1 & +4 \\
\hline Changes in tax policy & 3 & 3 & -1 & -9 \\
\hline Inflation growth rate & 2 & 2 & -1 & -4 \\
\hline $\begin{array}{l}\text { Increasing electricity, water tariffs } \\
\text { and other resources }\end{array}$ & 2 & 2 & -1 & -4 \\
\hline Price increase of raw materials & 2 & 3 & -1 & -6 \\
\hline Population mobility growth & 3 & 1 & +1 & +3 \\
\hline $\begin{array}{l}\text { Improving the solvency of the population } \\
\text { (including through loans) }\end{array}$ & 3 & 3 & +1 & +9 \\
\hline Fall of living standards of the population & 3 & 3 & -1 & -9 \\
\hline $\begin{array}{l}\text { Increased number of families not provided } \\
\text { with housing }\end{array}$ & 2 & 2 & +1 & +4 \\
\hline The development of small business & 3 & 3 & -1 & -9 \\
\hline $\begin{array}{l}\text { Development of scientific } \\
\text { and technical progress }\end{array}$ & 3 & 3 & +1 & +9 \\
\hline $\begin{array}{c}\text { The advent of new technologies, } \\
\text { equipment, materials }\end{array}$ & 3 & 3 & +1 & +9 \\
\hline $\begin{array}{l}\text { State support for innovation, } \\
\text { intellectual property }\end{array}$ & 3 & 2 & +1 & +6 \\
\hline
\end{tabular}




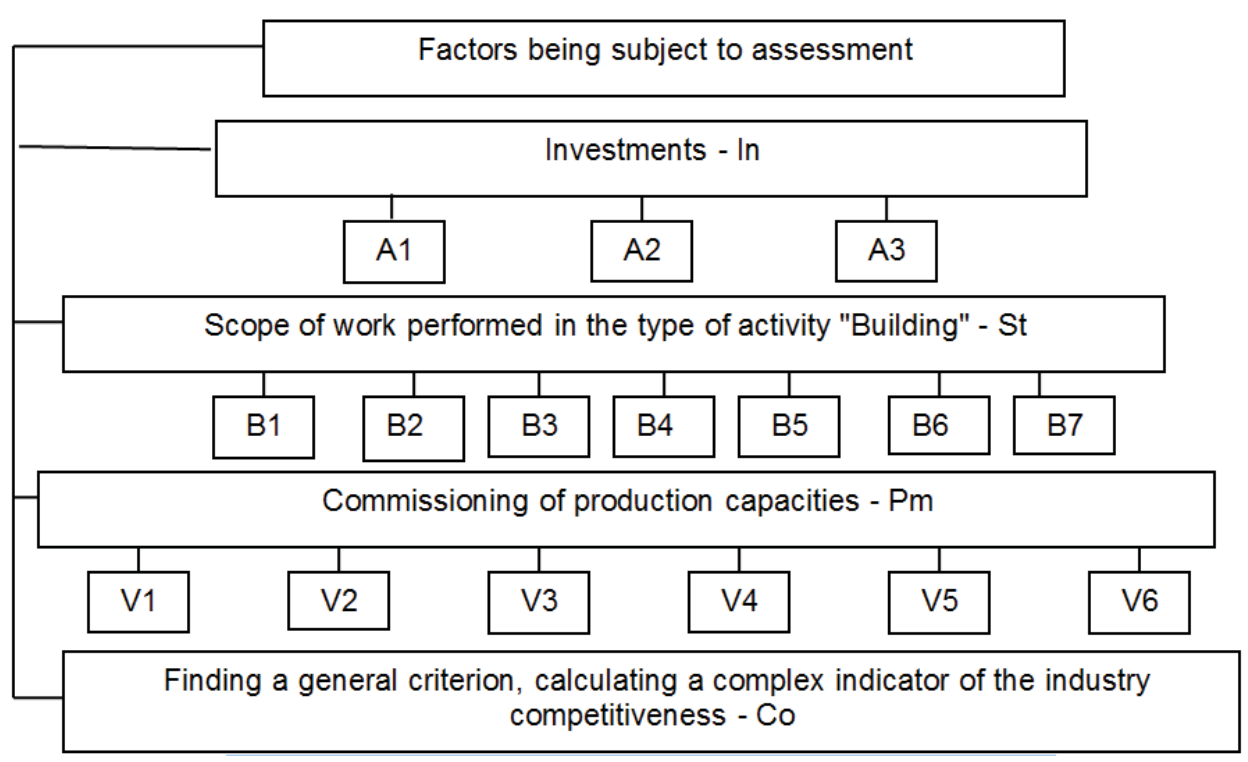

Figure 2: Evaluation scheme of the industry competitiveness

Data processing was carried out as follows: the elements of each column of judgment matrix were divided by the sum of the elements in that column, that is the column has been normalized; then the elements of each linewere summed and this amount was dividedby the number of elements in the line, that isthere has been made averaging over normalized columns [11]. The matrix of judgments and the priorities vector for the I-th level of competitiveness indicators are presented in Table 4.

It follows from the values of the priorities vector that the most important criteria are $\mathrm{Vp}$ (Volume of construction materials) and In (investments). The calculated priorities for competitiveness factors are presented below.

$$
\begin{aligned}
& \text { Co }=(\mathrm{In} ; \mathrm{Vp} ; \mathrm{Pm})=(0,309 ; 0,498 ; 0,193), \\
& \text { In }=(\mathrm{A} 1 ; \mathrm{A} 2 ; \mathrm{A} 3)=(0,395 ; 0,344 ; 0,261), \\
& \mathrm{Vp}=(\mathrm{B} 1 ; \mathrm{B} 2 ; \mathrm{B} 3 ; \mathrm{B} 3 ; \mathrm{B} 4 ; \mathrm{B} 5 ; \mathrm{B} 6 ; \mathrm{B} 7)= \\
& (0,103 ; 0,231 ; 0,202 ; 0,129 ; 0,117 ; 0,121 ; 0,097), \\
& \mathrm{Pm}=(\mathrm{V} 1 ; \mathrm{V} 2 ; \mathrm{V} 3 ; \mathrm{V} 4 ; \mathrm{V} 5 ; \mathrm{V} 6)= \\
& (0,268 ; 0,186 ; 0,188 ; 0,154 ; 0,102 ; 0,102)
\end{aligned}
$$

After determining the weight coefficients of all competitiveness criteria there have been evaluated some specific competitiveness indicators of industry complexes in the six regions. Since indicators are many and they have different dimensions, it is necessary to evaluate these criteria on a single scale for their adequate inclusion in the analysis process and the construction of an integral indicator, i.e. to move to certain uniform characteristics. However, the factors can play a stimulating role (stimulants) and disincentive one (disincentives).

Taking into account this fact for the transition to uniform characteristics, it is possible to use a method similar to the calculation of Human Development Index used by the UN.
In the function of $X \max j$ and $X \min j$ there have been taken the maximum and minimum value of criterionj, on the basis of this indicator for the last 6 years in 6 regions, i.e. $X \max j=\max \left({ }^{X i j}\right.$ for 6 years), $X \min j=\min (X i j$ for 6 years) (Table 5).

On the basis of formulas (1) and (2) there have been calculated the scaled values of the III level criteriaand corrected their weighting coefficients.

$$
\begin{array}{ll}
X m i j=\frac{X i j-X \min j}{X \max j-X \min j} & \text { - for stimulants } \\
X m i j=\frac{X \max j-X i j}{X \max j-X \min j}, & \text { - for disincentives }
\end{array}
$$

where $X m i j$ - the scaled value of an indicator $j$ for a region $i$ in a year $n ; X i j$ - actual value of an indicator $j$ for a region $i$ in a year $n ; X \min j-$ minimum value of an indicator $j$ for years $n$ in regions $i ; X \max j$ - maximum value of an indicator $j$ for years $n$ in regions $i$.

Then there was used the technique of forming an integral index, based on the theory of pattern recognition (Formula 3).

The model used in the techniqueis based on a comparison of normative (target or reference) indicators with the actual ones that characterize the achieved state of an evolving entity (in our case - industrial complex). The essence of this model lies in the following. Each entityis characterized by a set of parameters C. The two of the investigated entities are different, if there is at least one indicator $\mathrm{P}_{\mathrm{i}}$ from a set $\mathrm{C}^{\mathrm{a}}$ describing the entity "a" is numerically different from the indicator $P_{i}$ from a set $\mathrm{C}^{b}$ describing the object " $\mathrm{b} "$. In other words, if $\mathrm{C}^{\mathrm{a}}=\left\{\mathrm{P}_{1}^{\mathrm{a}}\right.$, $\left.\mathrm{P}_{2}^{\mathrm{a}}, \ldots, \mathrm{P}_{\mathrm{n}}^{\mathrm{a}}\right\}$ and $\mathrm{C}^{\mathrm{b}}=\left\{\mathrm{P}_{1}^{\mathrm{b}}, \mathrm{P}^{\mathrm{b}}, \ldots, \mathrm{P}^{\mathrm{b}}{ }_{\mathrm{n}}\right\}$ are the patterns of two entities, $\mathrm{Ca} \neq \mathrm{Cb}$, if at least one of the indicators $\mathrm{Pai} \neq \mathrm{Pbi}$. 
Table 4: Matrix of judgments and priorities vector for the I-th level of competitiveness factors of construction industry enterprises

\begin{tabular}{|c|c|c|c|c|}
\hline Co & Investments & Construction & $\begin{array}{c}\text { Commissioning of } \\
\text { production capacities }\end{array}$ & $\begin{array}{c}\text { Priorities } \\
\text { vector }\end{array}$ \\
\hline Investments & 1 & $1 / 2$ & 2 & 0,309 \\
\hline $\begin{array}{c}\text { Production volume of } \\
\text { building materials }\end{array}$ & 2 & 1 & 3 & 0,498 \\
\hline $\begin{array}{c}\text { Commissioning of } \\
\text { production capacities }\end{array}$ & $1 / 2$ & $1 / 3$ & 1 & 0,193 \\
\hline
\end{tabular}

Table 5: Maximum and minimum values of competitiveness of level III

\begin{tabular}{|c|c|c|c|c|c|}
\hline Criterion & Xmaxj & Xminj & Criterion & Xmaxj & Xminj \\
\hline A1 & 2,4 & 0,31 & B6 & 6,2 & 0,9 \\
\hline A2 & 16,1 & 3,3 & B7 & 0,69 & 0,08 \\
\hline A3 & 6,8 & 0,9 & V1 & 0,86 & 0,17 \\
\hline B1 & 6,4 & 1,5 & V2 & 0,54 & 0,13 \\
\hline B2 & 10,1 & 0,9 & V3 & 7,2 & 1,7 \\
\hline B3 & 36,2 & 19,5 & V4 & 23,9 & 1,9 \\
\hline B4 & 8,95 & 1,21 & V5 & 16,9 & 3,8 \\
\hline B5 & 0,201 & 0,024 & V6 & 16,2 & 3,4 \\
\hline
\end{tabular}

Table 6: Summary data of construction sector competitiveness in the regions of the Russian Federation Central Federal District

\begin{tabular}{|c|c|c|c|c|c|c|}
\hline Regions & Investments & Rating & $\begin{array}{c}\text { Production level of } \\
\text { building materials }\end{array}$ & Rating & $\begin{array}{c}\text { Implementation of } \\
\text { production capac- } \\
\text { ities }\end{array}$ & Rating \\
\hline the Belgorod Region & 0,264502 & 2 & 0,476548 & 2 & 0,117206 & 2 \\
\hline the Voronezh Region & 0,307707 & 1 & 0,487277 & 1 & 0,121675 & 1 \\
\hline the Kursk Region & 0,255332 & 3 & 0,416193 & 5 & 0,108788 & 3 \\
\hline The Lipetsk Region & 0,220149 & 5 & 0,474108 & 3 & 0,095736 & 4 \\
\hline the Oryol Region & 0,230887 & 4 & 0,411139 & 6 & 0,08735 & 5 \\
\hline the Tambov Region & 0,205265 & 6 & 0,416536 & 4 & 0,079899 & 6 \\
\hline
\end{tabular}


Let's call $\mathrm{C}^{\mathrm{a}}$ the reference entity. All the indicators of the reference entity are assigned limit values. The calculations begin with the calculation of differences between the actual indicators of the investigated entity (Pfi) and the reference one (Pei). The degree of proximity of the actual image to the reference one is calculated by the means of the formula:

$$
\begin{aligned}
& Y i=1-\frac{\text { dio }}{C o} \\
& \text { dio }=\sqrt{\sum_{j=1}^{n}(x i j-x o j)^{2}}, C o=\bar{x}+2 S d \\
& \bar{x}=\frac{1}{t} \sum_{i=1}^{t} \text { dio }, \quad S d=\sqrt{\frac{1}{t} \sum_{i=1}^{t}(\text { dio }-\bar{x})^{2}}
\end{aligned}
$$

\section{where}

$x i j$ - the implementation of propertyjin entityi (Pf);

$x o j$ - the implementation of property $\mathrm{j}$ in the reference entity $(\mathrm{Pe})$.

The technique makes it possible totake into account the distance between the investigated entities,to consider their competitiveness in the aspect of time, to analyze regressional relationship of independent and resulting indicators [01].

In our case, the entity is the competitiveness of construction industry in the region. Competitiveness is characterized by three indicators of II level, each of which is composed of a set of indicators of III level. So, that is why first we shall find $\mathrm{Yi}$ for each indicator of II level. Since all the indicators of III level were evaluated on a single scale from 0 to 1 and converted to the stimulants (the region having the best indicator value for 4 years received 1 this year), and then the scaled values are multiplied by the weighting coefficients of these indicators, thenthe reference values of the indicators in this case will be their weighting coefficients.

Further, the obtained integral indicators of II level (In, St, $\mathrm{Pm}$ ) are multiplied by the previously calculated weighting coefficients. Then with the help of formula (3) the integral indicator of the industry competitiveness of level I - Co is being formed. Table 6 presents summary data on the competitiveness of construction industry in the regions.

The results show that in regard to the production capacities the enterprises of the construction industry in the Voronezh and Belgorod Regionsare the most competitive ones. These regions are marked by not only a high level of investment in fixed capital, production of building materials, the construction of residential buildings but also by high volume of commissioning of houses and apartments.

In terms of construction materials production the most competitive ones are the Voronezh, Belgorod and the Lipetsk Regions; Kursk region is in the fifth place. However, as regards the quality of raw materials and level of construction materials availability the Kursk Region has sufficient potential to improve these indicators [13].

According to the results of a comprehensive analysisone can draw the following conclusions. The production of construction materials is best developed in the Voronezh Region. It is a leader in the production of building materials, which makes it less dependent on the suppliers of building materials and determines a stable position in the competitive struggle. The Belgorod Regionfirmly holds the second place as it carries out a rational utilization of their production capacities achieving high volume of construction materials productionby means of investments in fixed capital.

The development of raw materials base of the Kursk Region does not match its production capacities. The production of construction materials in the Kursk Regionshould, at least, correspond to the indicators of the Voronezh Region, and at the best case, surpass it.

The key indicator of the studied industry competitiveness is the production of construction materials. In connection with the situation in the market enterprises can only increase the production of building materials, through the development of own raw-material base of building materials production. It followsfrom this that the Kursk Region needs to improve the following directions: development of raw material areas of construction industry enterprises; expansion plan, reconstruction and technical re-equipment of enterprises (production plan).

Analysis testified that Russian industry is in a crisis phase. The economy objectively needs expansion of industrial production. Numerous national experts' discussions are devoted to this topic. It is declared as the aim of governmental policy. Perspectives of innovation-driven renewal of Russian economy have to be abandoned if this problem is not resolved. Target declared in national Strategy for innovative development to switch Russian economy to innovative way of development till 2020 (this implies an increase in the share of industrial enterprises, implementing technological innovations, up to 40 50 percent; the increase of Russia's share on the world markets of hi-tech goods and services to 5-10 percent in 5-7 or more sectors of the economy; increasing the share of exports of the Russian high-tech goods in total world exports of such goods to 2 percent, etc.) will not be achieved.

Concerns about continuing stagnation in manufacturing industry are associated with monetary policy. We believe that modern Russian realities require a different approach to the regulation of economic and, in particular industrial development. Situation calls for:

- Active industrial policy;

- Stronger participation of state authorities in load of production capacities (through state orders, privileges on updating of the basic production assets, export promotion, implementation of protective measures under the WTO procedures and others) and the management of its development; 
- Revision of the basic principles of monetary policy. It has to play secondary roles and be aimed at alimentation of economic growth and development of national innovational manufacturing industry [02]

\section{CONCLUSION}

In economic science, in addition to micro-, macro -, and mega - levels, the theory of competition actualizes the problem of singling out ameso-level, i.e. the level of industries. A industry's competitiveness is largely determined by the competitiveness of its constituent firms, and, consequently, the competitiveness of manufactured goods.

To ensure the development and stable functioning of a building complex it is necessary to reorganize the existing system, in which one should identify the priority areas for management.

Improving and increasing management efficiency of investment processes in the construction industry entails the production and output of competitive construction products, the elimination of unprofitable construction companies, improving the quality of construction services, as well as the providing of population with construction facilities (housing, community facilities, etc.).

For analysis and evaluation of sectoralenterprisescompetitiveness there can be used various methods which take into account the peculiarities of the sector in question, the availability of information and the objectives of the study. Valuation techniques based on the theory of effective competition, which may address issues of competitiveness in the aspect of time according to the market strategy of an enterprise are of great value here. The approaches based on the concept of quality of goods do not contain plain and unambiguous criteria that would allow assessing the competitiveness, but they characterize market activity of enterprises. The method of assessing the competitiveness of enterprises taking into account the temporal characteristics is the most attractive one. Each approach to competitiveness evaluationshould be developednot for all enterprises. It should be developed for specific groups of enterprises.

Introduction of model of enterprise competitiveness management, will allow the enterprise, to increase productivity of administrative decisions concerning questions of optimization of production resources, introductions of innovations and innovative technologies for increase of competitiveness of the enterprise [16].

The well-known methods imply the existence of a competitive environment, they do not take into account the situation of the transition period and are applicable to the enterprises producing homogeneous products, and they alsoexclude the possibility of assessing the competitiveness of one and the same sectoral level enterprises manufacturing different products.
Therefore, to determine the competitiveness of the building complex our paper proposes to use the integral criterion based on pattern recognition theory, which allows usto simultaneously compare the activities of all enterprises of the complex.

\section{REFERENCES}

1. Azoev G.L. (1996) Competition: analysis, strategy and practice. - Moscow: Center of economics and marketing, 1996. - $205 \mathrm{p}$.

2. VertakovaYu.V., Plotnikov V.A. (2013) Theoretical aspects of considering the dynamic characteristics of socioeconomic systems in the management of regional developmentRegional Research of Russia. 2013. T. 3. No. 1.Pp. 89-95.

3. VertakovaYu.V. (2005) Indicative planning of reproduction proportions of sustainable development of region's economy: monograph / Yu.V. Vertakova. Moscow: Higher School, 2005. - 352 p.

4. Voronin V.A. (2006) Models and mechanisms of assessing the efficiency of building organization integration / V.A. Voronin // Industrial and civil construction. - 2006. - No.9. Pp. 60-62.

5. Gel'vanoskij M.I. (1998) Competitiveness at the micro-, meso-, and macro-level measurement // Russian Economic Journal. - 1998. - No.3. Pp. 67-77.

6. State regulation of national economy: teaching aid / E.V. Kharchenko, Yu.V. Vertakova (2011). 5th edition, revised andcomplemented - Moscow: KNORUS, 2011. - 328 p.

7. Larionov A.I. (1991)Economic and mathematical methods in planning. - Moscow: Higher School, 1991. - $240 \mathrm{p}$.

8. Industrial competitiveness of EU member states: some progress made, but many challenges still lay ahead, Brussels, 25 September 2013.

9. Milgunova I.V. (2008) Forming and implementing the integration strategy of development of building materials: author's abstract of Ph.D in Economics: 08.00.05 / MilgunovalrinaViktorovna; [Place of thesis defence: Oryol State Technical University]. - Oryol, 2008. - 23 p.

10. Porter M.E. (2003) Competition: Translated from English / M.E. Porter. Moscow: Publishing house "Williams", 2003. $496 \mathrm{p}$.

11. Saati T.L. (1989) Decision making. Hierarchy analysis method. - Moscow: Radio and communication, 1989. - $316 \mathrm{p}$.

12. Fatkhutdinov R.A. (2000) Competitiveness: economy, strategy, management. - Moscow: Infra-M, 2000. $-312 \mathrm{p}$. 
13. Forming and assessing the competitive advantages of industrial enterprises: monograph / I.V. Milgunova, Yu.V. Vertakova, T.S. Kolmykova (2012); SouthWest State University. Kursk, 2012. - 152 p.

14. H. Chang Moon, Newman S. Peery, Jr., (1995) "Competitiveness of product, firm, industry, and nation in a global business», Competitiveness Review: An International Business Journal, Vol. 5 Iss: 1.Pp. $37-43$.

15. Porter M.E. (1985) Competitive Advantage: Creating and Sustaining Superior Performance. - New York: The Free Press, - 1985. - 387 p.
16. Safiullin M.R., Samigullin I.G. and Safiullin L.N. (2013) Model of Management of Competitiveness of a Machine-building Complex. - World Applied Sciences Journal 27 (Economics, Management and Finance): 212-216, 2013.

17. https://en.wikipedia.org/wiki/Human_Development Index\#New_method_.282010_Report_onwards. 29 